Animal Health Research Institute, Assiut Regional Laboratory

\title{
ISOLATION OF S. ENTERITIDIS AND OTHER SALMONELLAE FROM CREAM AND IT'S STABILITY AGAINST SORBATES AND HONEY
}

(With 2 Tables)

\author{
By
}

\author{
NAHED M. WAHBA; EMAN KORASHY A. \\ and M.W. Abd. AL-AZEEM*
}

*Dept. of Microbiology, Fac. Vet. Med., South Valley Univ.

(Received at 18/11/2008)

\section{عزل السالمونيلا المعوية والسالمونيلا الأخرى من الكريمة ومدى ثباتها

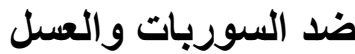

\section{ناهد محمد وهبه ، إييان قرشسي /حمد ، محمد وائل عبل العظيم}

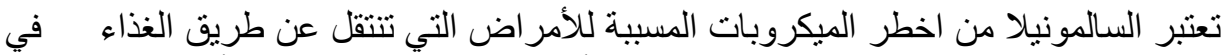

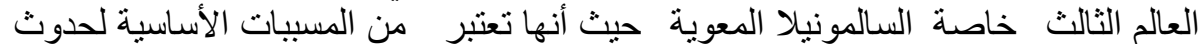

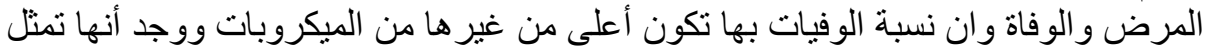

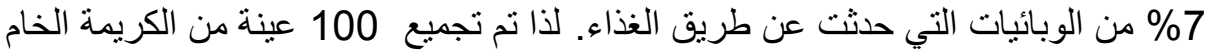

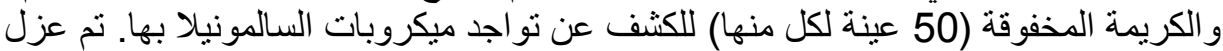
15 ، 14 عزله مبدئيا على كل من

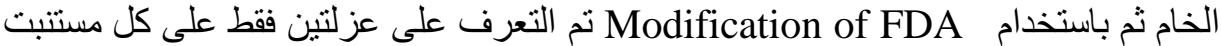

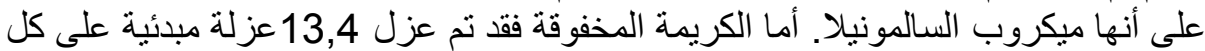

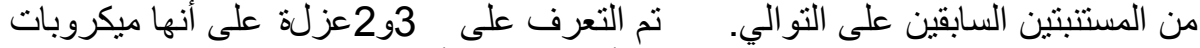

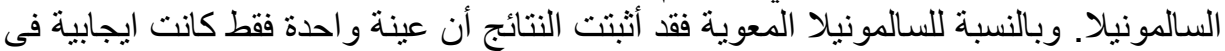

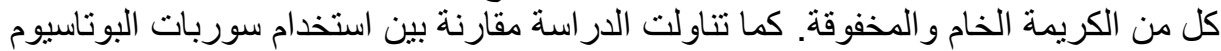

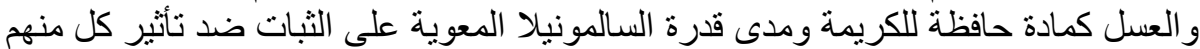

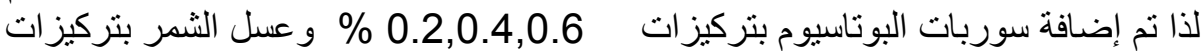

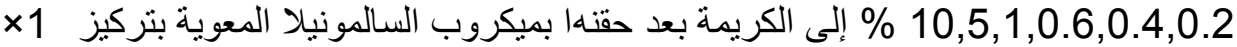

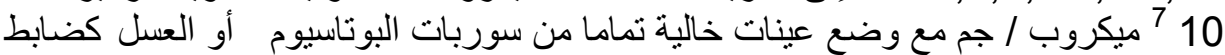

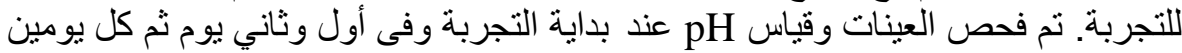

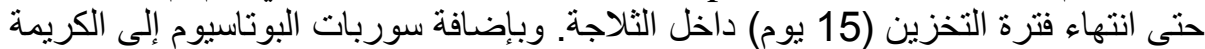

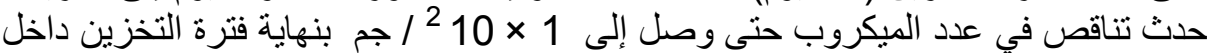

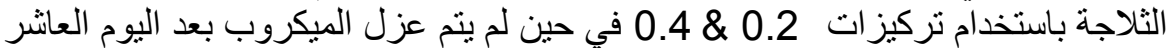

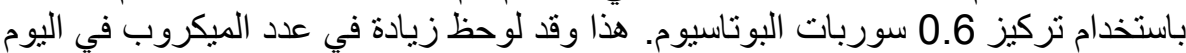

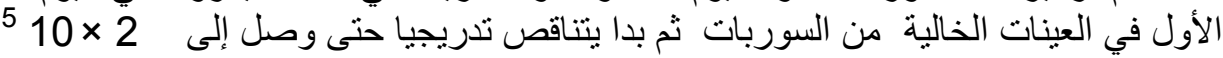




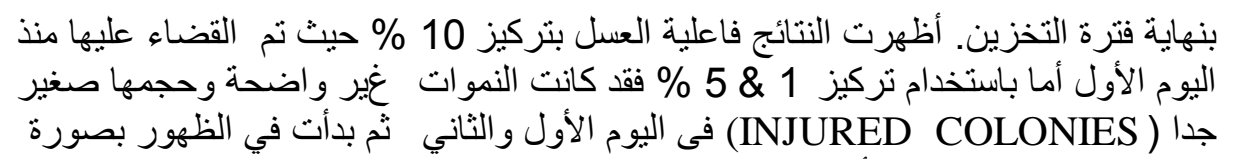

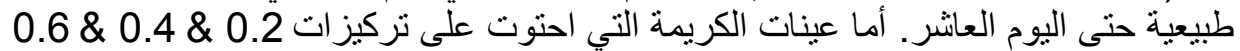

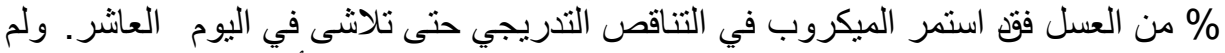

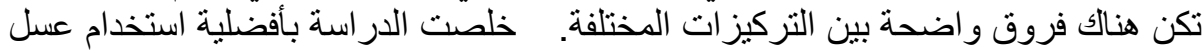

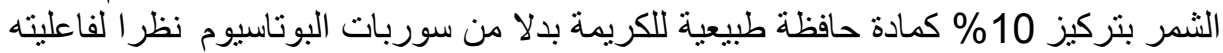
في القضاء على السالمونيلا خلال 24 ساعة وقيرة وليمته الغذائية المرتفعة.

\section{SUMMARY}

100 random samples of raw and whipped cream (50 samples each) were tested for the presence of S. enteritidis and other Salmonella spp. From raw cream 15 and 14 initial Salmonella isolates were recovered using S.S. and Bismuth sulphite agars, respectively. Only 2 isolates were identified as Salmonella spp. on both media on the basis of modefication of FDA. Regarding whipped cream, 13 and 4 presumptive Salmonella colonies were isolated on the same media, of these, 3 and 2 isolates were identified as Salmonella spp on both media respectively. The stability of $S$. enteritidis against potassium sorbate or honey in cream stored at refrigerator temperature was studied. Cream inoculated with $1 \times 10^{7} \mathrm{~S}$. enteritidis, devided into 10 parts to which potassium sorbate was added, in concentrations of $0.2,0.4$ and $0.6 \%$. Fennel honey was added in concentrations of $0.2,0.4,0.6,1,5$ and $10 \%$. One part was kept as control. The samples were examined for $S$. enteritidis count and $\mathrm{pH}$ in the $1^{\text {st }}$ and $2^{\text {nd }}$ day then, every 2 days of storage. Lower decrease in count of $S$. enteritidis was noticed in cream containing $0.2,0.4$ and $0.6 \%$ pot .sorbate, stored at refrigerator temperature. Undetectable numbers of S. enteritidis were observed at $10^{\text {th }}$ day in concentration of $0.6 \%$. While, in control samples the count reached $8 \times 10^{7}$ in the $1^{\text {st }}$ day then, decraesed to be $2 \times 10^{5}$ at the end of the storage time. In contrast, addition of honey at conc. of $10 \%$ inhibits the growth of $S$. enteritidis within 24 hours of storage at refrigerator temperature. Lower concentration of honey ( 1 and $5 \%$ ) led to appearance of injured colonies in the $1^{\text {st }}$ and $2^{\text {nd }}$ day, the colonies begin to recover at the $4^{\text {th }}$ day, and no viable cells were noticed after the $10^{\text {th }}$ day. Gradual reduction in the count of S. enteritidis using $0.2,0.4$ and $0.6 \%$ honey was observed till the $10^{\text {th }}$ day. Our results showed which preservative is most active against $S$. enteritidis, thus, the safety of cream could be improved by addition of fennel honey in a concentration of $10 \%$. 
key words: Cream, Salmonella, sorbates, honey

\section{INTRODUCTION}

Despite of the extensive public health measures over the past century, Salmonella remains the second most commonly identified cause of bacterial foodborne disease in the developed countries and a signficant cause of morbidity and mortality in the developing world (Edward, 1999; Abdou et al. 2001; WHO, 2002). In Egypt salmonellae were found in $3 \%$ cases of children diarrhea in rural areas and $4 \%$ in urban areas. In Upper Egypt, salmonellae were detected in $14.8 \%$ of cases of children diarrhea (FAO, 1993)

S. enteritidis continued to be a major cause of illness and death. It is the most common serovar causing approximately $80 \%$ of foodborne salmonellosis cases (WHO, 1998). Moreover, it results in more deaths than any other pathogen (Olsen et al., 2000).

Cream is a popular dairy variety; it was added as an ingredient to a large number of commercial food products. It could be a vehicle of transmitting Salmonella (Nasseib et al., 2003). Cream is one of the perishable dairy products which has high moisture content and enjoys only a limited shelf life. Pasteurized cream is one of the slow moving goods in the Egyptian markets, so the recommended shelf life is considered short and may constitute an economic problem due to its spoilage on shelves and evidence of public health threat (Abdou et al. 2001).

Preservatives either chemical or natural are used to prevent or retard both chemical and biological deterioration in foods (Davidson and Branen 1993). At the moment sorbic acid and its salts especially potassium sorbate has been used extensively in food (Beek et al., 2007). Many previous reports studied the inactivation of Salmonella spp, using pot. sorbate (Rice and Pierson 1982; Tuncan and Martin 1985; Larocco and Martin 1987 and Alvarez et al., 2007 ).

Use of sorbic acid in foods is permitted in most countries which regulate their food supply (Luck 1980), the maximum permissible level other than in exceptional situations is between $0.1 \%$ and $0.2 \%$ (Code of Federal Regulations 1981). Environmental factors such as $\mathrm{pH}$, water activity, temperature, microbial load, type of microbial flora and certain food components can influence the effectiveness of sorbic acid. All these factors should be considered when using sorbic acid and its salts as antimicrobial preservatives (Liewen and Marth 1985). 
A possible shift to the use of naturally occurring antimicrobials increased in the future. Since, these compounds have been in the food supply and consumed for a number of years. They appear to be safe and not require a new synthetic compound (Davidson and Branen 1993).

The antibacterial property and preservative nature of honey had been studied (Badway et al., 2004; Mundo et al., 2004; Ali et al., 2005 and Krushna et al., 2007). Honey which is - chiefly a combination of various sugars and hydrogen peroxide - can be used as a preservative of milk due to firstly the bactericidal property of hydrogen peroxide (Krushna et al., 2007), and secondly, it contains syringic, methyle syringate and other aromatic acids in honey that are structurally simillar to benzoic acids which are typically used in foods as preservatives (Russel et al., 1990).

Although honey is a safe natural product prevents growth of Gve, G+ve and C. albicans (Al-Waili et al., 2005). The ability of honey to inhibit the growth of microorganisms varies widely and the bacteria were not uniformly affected by honey (Mundo et al., 2004).

So, the present work firstly aimed to isolate Salmonella spp from raw and whipped cream and secondly to study the stability of S. enteritidis against pot. sorbate and honey in cream.

\section{MATERIALS and METHODS}

\section{Isolation of Salmonella spp from cream samples}

100 random samples of raw and whipped cream (50 samples each) were collected from different localities in Assiut City. Cream samples were thawed in water both adjusted at $40^{\circ} \mathrm{C} / 10$ minutes according to Al Ashmawy et al. (2002).

Cream samples were preenriched on lactose broth and selectively enriched for Salmonella spp. in Selenite F broth at $37^{\circ} \mathrm{C}$ for 24 hours. S.S. agar and Bismuth sulphite agars were used to isolate Salmonella spp. according to Janda and Abott (1998) and Andrews and Hammack (2001). Pink colonies with black center on S.S. agar as well as the black colonies on Bismuth sulphite agar were identified as Salmonella spp. by Gram stain and various biochemical tests as described by Benson (1994) and Stephen and Caren (1997). Modification of the confirmatory process indicated by FDA $(1995,2001)$ protocols was done.

\section{The stability of $S$. enteritidis against sorbates and honey in cream}


Pasteurized cream (23\% milk fat free from preservatives) was inoculated with a suspension of 24 hours incubation of $S$. enteritidis strain at a concentration of $1 \times 10^{7} \mathrm{cfu} / \mathrm{ml}$. S. enteritidis strain was identified serologically by the Central Administration for Laboratories of Health Ministry, Cairo. Egypt and obtained from Dept. of Food Hygiene Fac. Vet. Med. Assiut Univ.

Cream samples were divided into 10 parts. Pot. sorbates was added to 3 parts at concentrations of $0.2,0.4$ and $0.6 \%$. Fennel honey was added to 6 parts to achieve final concentrations of $0.2,0.4,0.6,1,5$ and $10 \%$. The last part was kept as a control. Sample was taken to determine the initial count and $\mathrm{pH}$.

The inoculated parts as well as the control were kept in the refrigerator $\left(4 \pm^{\circ} \mathrm{C}\right)$ for a period of 15 days which is the shelf life of the pasteurized cream as recommended by the manufacturer. Samples were taken from each part to determine the count of S. enteritidis and $\mathrm{pH}$ at time zero, first and second day and every 2 days untill the end of the storage period.

\section{RESULTS}

The results were shown in Tables 1 and 2

Table 1: Incidence of Salmonella spp. in the examined cream samples:

\begin{tabular}{|c|c|c|c|c|c|c|c|c|}
\hline \multirow[t]{2}{*}{ Samples } & \multirow[t]{2}{*}{$\begin{array}{c}\text { No.of } \\
\text { examined } \\
\text { samples }\end{array}$} & \multirow[t]{2}{*}{ Media used } & \multicolumn{2}{|c|}{$\begin{array}{c}\text { Presumptive } \\
\text { Salmonella } \\
\text { colonies } \\
\end{array}$} & \multicolumn{2}{|c|}{$\begin{array}{l}\text { Positive Salmonella } \\
\text { spp. }\end{array}$} & \multicolumn{2}{|c|}{ S. enteritidis } \\
\hline & & & No. & $\%$ & No. & $\%$ & No. & $\%$ \\
\hline Raw cream & 50 & $\begin{array}{c}\text { S.S.agar } \\
\text { Bismuth sulphite } \\
\text { agar }\end{array}$ & $\begin{array}{l}15 \\
14\end{array}$ & $\begin{array}{l}30 \\
28\end{array}$ & $\begin{array}{l}2 \\
2\end{array}$ & $\begin{array}{l}4 \\
4\end{array}$ & $\begin{array}{l}1 \\
1\end{array}$ & $\begin{array}{l}2 \\
2\end{array}$ \\
\hline $\begin{array}{l}\text { Whipped } \\
\text { cream }\end{array}$ & 50 & $\begin{array}{c}\text { S.S.agar } \\
\text { Bismuth sulphite } \\
\text { agar }\end{array}$ & $\begin{array}{c}13 \\
4\end{array}$ & $\begin{array}{c}26 \\
8\end{array}$ & $\begin{array}{l}3 \\
2\end{array}$ & $\begin{array}{l}6 \\
4\end{array}$ & $\begin{array}{l}1 \\
1\end{array}$ & $\begin{array}{l}2 \\
2\end{array}$ \\
\hline Total & 100 & & 46 & 46 & 9 & 9 & 4 & 4 \\
\hline
\end{tabular}


Assiut Vet. Med. J. Vol. 55 No. 120 January 2009

\section{DISCUSSION}




\section{Isolation of Salmonella spp. from cream}

Foodborne salmonellosis continues to be a major health concern world wide (kiessling et al., 2007) thus, detection of salmonella isolates is of interest. The literature dealing with the prevalence of salmonella in cream is very scanty However, salmonella spp. were isolated from $3.32 \%$ of food samples by Wang et al. (2004) and $5.9 \%$ by Kiessling et al. (2007). In the present study, (15\&14) and (13\&4) presumptive salmonella colonies recovered from raw and whipped cream using S. S and Bismuth sulphite agars, respectively (Table1). On the basis of modification of FDA 2 isolates (4\%) were identified as Salmonella spp. From raw cream on both media. However $3(6 \%)$ and $2(4 \%)$ isolates were proved to be Salmonella spp. from whipped cream on S.S and Bismuth sulphite agars, respectively. Only one sample from each of raw and whipped cream contain S. enteritidis (Table1).

Salmonella spp. was previously isolated from cream samples by El- Kosi (2001) and Nasseib et al. (2003) while, it failed detection by El Saied (1985). The use of the modification of FDA to confirm Salmonella spp. was recommended; out of 46 presumptive Salmonella colonies, 9 isolates were proved to be Salmonella spp. (Table1). Also Nasseib et al. (2003) recommended the modification of the confirmatory process indicated by FDA $(1995,2002)$ as they found that only 7 out of 247 initial isolates were identified as Salmonella spp. using this modification.

Salmonellae are frequently isolated from dairy cattle and from various dairy farm environments such as water, feed, and manure. Moreover, asymptomatic shedding of Salmonella in feces also occurs, it follows that there is a risk of the pathogen entering the bulk tank through fecal contamination (Troutt et al. 2001 and Huston et al. 2002). Using raw milk in the preparation of cream could serve as a contaminating point. Salmonella spp. were isolated from raw milk in variable percentages 8\% (Rohrbach et al., 1992), 6.6\% (Sayed 2002), 28\% (El Said 2002), 6\% (Amin 2004) while, failed detection by Sharma et al. (1995).

Our results suggest negligence such as poor sanitation during preparation of raw and whipped crèam. Additionally, the possibility of contamination by carrier food handlers and the temperature abuse considered a major contributary factors (Varnam and Sutherland, 1994).

Although, there are relatively low numbers of positive samples in this study, the pathogen represent a potential risk to consumers on the 
basis that all salmonellae are potentially pathogenic (Zansky et al., 2002).

\section{The stability of $S$. enteritidis against sorbates and honey in cream}

The weak organic acid, sorbic acid, and its salts are commonly used as food preservatives, as they inhibit the growth of bacteria, yeasts and molds (Beek et al., 2007). In general, two theories have been postulated to explain the inhibitory mechanism of sorbate. One of these is carried out by the inhibition of one or more vital microbial enzymes (Sofos and Busta, 1981); the other mechanism is carried out by the inhibition of nutrient uptake (Tuncan and Martin, 1985 and Beek et al., 2007).

Our results demonstrated a slow decrcase in the count of S.enteritidis in cream containing various concentrations of pot. sorbate. The organism was still detected well till the end of the storage time at $0.2 \%$ and $0.4 \%$ pot. sorbate. There was no death or injury observed in these samples throughout the storage. On the other hand, Rice and Pierson (1982) found that concentration of 0.26 and $0.39 \%$ pot. sorbate were effective in inhibiting Salmonella.

As the storage time increased, cells of Salmonella were stressed at a faster rate (Larocco and Martin 1987). The numbers of bacteria diminished gradually till the $6^{\text {th }}$ day then, decreased in a faster rate reaching $1 \times 10^{2}$ at the end of $15^{\text {th }}$ day in cream samples containing 0.2 and $0.4 \%$ pot. sorbates (Table 2). Inhibition of growth of microorganisms was increased by increasing sorbate concentration (Sofos and Busta 1981). By increasing the concentration to $0.6 \%$ no viable cells were detected after 10 days (Table 2). This may be referred to the effect of $\mathrm{pH}$, samples that contained pot. sorbate had $\mathrm{pH}$ ranged from 7.4-6.1 this $\mathrm{pH}$ may contribute the action of pot. sorbate, Environmental factors such as $\mathrm{pH}$ can influence effectiveness of sorbate (Liewen and Marth 1985). Furthermore Park and Marth (1972) found that $0.3 \%$ sorbic acid at $\mathrm{pH} 5$ inactivated Salmonella in 12 hours. As noted earlier, the maximum permissible level of sorbates, other than in exceptional situation is between $0.1 \%$ and $0.2 \%$ (Code of Federal Regulations 1981).

In control samples the count increased to $8 \times 10^{7}$ in the $1^{\text {st }}$ and $2^{\text {nd }}$ days then, decreased to reach $2 \times 10^{5}$ at the end of the storage time (Table 2). Since the $\mathrm{pH}$ of control samples ranged from 6.8-6.1, this reduction may attributed to the effect of refrigerator temperature through the storage period (15 days) 
In sharp contrast to cream without preservatives or cream with pot. sorbate, addition of honey at a conentration of $10 \%$ inhibit the growth of $S$. enteritidis within 24 hours of storage at refrigerator temperature (Table 2). High concentration of honey proved more effective as antibacterial agents (Badawy et al., 2004). Furthermore, honey combind with low temperature increased the inhibitory effect of honey (Russel et al., 1990)

Cream with honey had $\mathrm{pH}$ ranged from 6.8-5 (Table 2). Honey $\mathrm{pH}$ between 3-5 acts as inhibitory media to most pathogen that requires pH 7.2-7.4 for thier bioactivity (Molan, 1992).

The potency of honey as antimicrobial agent is thought due to its acedic $\mathrm{pH}$, its hyperosmolarity property and to hydrogen peroxide which is the main and principle bacterial growth inhibin in honey (Molan, 1992, and Al-Waili 2001). Fennel honey was the most potent and had the highest $\mathrm{H} 2 \mathrm{O} 2$ level among the different tested honey batches (Ali et al., 2005)

Low concentration of honey (1and 5\%) led to appearance of injured colonies in the $1^{\text {st }}$ and $2^{\text {nd }}$ days, the colonies begin to recover at the $4^{\text {th }}$ day. No viable cells were noticed after the $10^{\text {th }}$ day (Table 2). It was found that bacteria could overcome the antibacterial activity of honey after a period of inhibition (Molan, 1992). However, the appearance of microbial growth after initial inhibition by a single dose of honey might be a result of inability of such dose to kill all the growing isolates (Al- Waili et al., 2005).

Gradual reduction in the count of $S$. enteritidis till the $10^{\text {th }}$ day was observed using $0.2,0.4$ and $0.6 \%$ honey, the present findings coincided with Lusby et al. (2005) who found that little or no antibacterial activity was seen at honey concentrations $<1 \%$, with minimal inhibition at $5 \%$.

Not only honey acts as antibacterial agent, but also it reduced S. enteritidis adhering to the intestinal epithial cells in vitro (Al naqdy et al., 2005). Moreover, honey has been gaining interest as a substitute sweetener in foods due to its high nutritive value, palatability and inhibitory properties against pathogens (Somal et al., 1994).

Our results show which preservative is most active against S. enteritidis thus, the safety of cream could be improved by the addition of Fennel honey at a concentration of $10 \%$.

\section{REFERENCE}


Abdou, A.M.; Abou-Eleinin, A.M. and El Bagoury, A.M. (2001): Occurrence of thermoduric - psychrotrophs throughout the shelflife time of pasteurized cream, $1^{\text {st }}$ Cong. Food Hyg. Human health. Fac. Vet. Med. Assiut Univ. 205-217.

Al-Ashmawy, A.M. (2002): Food Hygiene Handbook. Fluid milk, Dairy produts, Fat \& Oil and Eggs. Fac. Vet. Med. El - Mansoura Univ.

Al-Walli, N.S. (2001): Identification of nitric oxide metabolitis in various honeys: effects of intravenous honey on plasma and urinary nitric oxidemetabolitis concentrations. J. Med. Food. 6: 359-64

Al-Waili, N.S.; Akmal, Al-Waili, F.S.; Saloom, K.Y. and Ali, A. (2005): The antimicrobial potential of honey from United Arab Emirates on some microbial isolates. Med. Sci. Monitor, 11:433-438.

Alnaqdy, A.; Jabri, A; Al Mahroqi, Z.; Nzeako, B. and Nsanze, H. (2005): Inhibition \& effect of honey on the adherence of Salmonella to intestinal epithelial cells in vitro. Int. J. Food Microbiol., 103: 345-351.

Ali, M.M; Wahba Nahed, M.; Abdel-Rahman, M.F. and Abdel-Hafeez, M.M. (2005): Antibacterial activity of honey for treatment of subclinical bovine mastitis: 1- In vitro study of bacterial inhibins and chemical bioassay of some different honeys $8^{\text {th }}$ Sci. Cong. Egyptian. Society for cattle diseases. PP 139- 146.

Alvarez, I.; Niemira, B.A; Fan, X. and Sommers; C.H. (2007): Inactivation of Salmonella enteritidis and Salmonella senftenberg in Liquid whole egg using generally recognized as safe additives, ionizing radiation and heat. J. Food Port. 70: 1402-1409.

Amin Walaa, F. (2004): Some studies on salmonella species in milk and some milk products in Assiut City. Mvsc. thesis Fac. Vet. Med. Assiut Univ. Egypt.

Andrews, W.A. and Hammack, T.S. (2001): Bacteriological. Analytical Manual on line. U. S. Food and Drug Administration. Center for Food Safety and Applied Nutrition.

Badawy, O.F.; Shafii, S.S.; Tharwat, E.E. and kamal, A.M. (2004): Antibacterial activity of bee honey; and its therapeutic usefulness against Escherichia coli O157: H7 and Salmonella typhimurium infection. Rev. Sci. Tech., 23: 1011-22. 
Beek, A.T.; Keijser, B.J.; Boorsma, A.; Zakrzewska, A.; orij, R.; Smits, G.J. and Brul, S. (2007): Transcriptome analysis of sorbic acid stressed Bacillus subtlis reveals a nutrient Limitation responce and indicates plasma membrane remodeling. J. Bacteriol (2007). $13^{\text {th }}$ December.

Benson, H.J. (1994): Microbiological applications: A laboratony Manual in General Microbiology $6^{\text {th }}$ Ed. W.M.C. Brown company pub. Dubuque lowa.

Code of Federal Regulations, (1981): Title 21 part, 133.

Davidson, P.M. and Branen, A.L. (1993): Antimicrobials in Foods. $2 \underline{\text { nd }}$ Ed. Marcel Dekker.

Edwards, P.H. (1999): Salmonella and Shigella species. Clinical Laboratory Medicine: 19: 469: 487.

El-Kosi, O.H.R (2001): Occurrence of some enetric pathogens and their indicators in some Egyptian raw milk products. Assiut Vet. Med., J. 45: 48-61

EL Said, E.I. (2002): Studies on food poisoning bacteria with special reference to Campylobacter jejuni in milk. Ph. D. thesis Fac. Vet. Med. Assiut. Univ. Egypt.

El Saied, M.S. (1985): Food poisoning organisms in milk and some dairy products in Zagazig. Ph, D. thesis Fac. Vet. Med., Zagazig Univ. Egypt.

FDA (1995): FDA Bacteriological Analytical Manual. Arlington, V A :Association \& Official Analytical Chemists.

FDA (2002): FDA Bactriological Analytical Manual, 8thed. washington, DC : US Food and Drug Administration ( http://www.vm.cfsan.fda.gov/webam/bam-s.html).

FAO (Food and Agriculture Orgainzation) (1993): Zoonotic diseases in the Near East Region Regional Office of the Unitied Nations, Cairo.

Huston, C.L.; Wiltum, T.E.; Love, B.C. and keen, J.E. (2002): Prevalence of fecal shedding of Salmonella spp. in dairy herds. J. Am. Vet. Med. Assoc. 220: 645-649.

Janda, T.M. and Abott, S.L (1998): The salmonellae. In Enterobacteria lippincott - Raven Pub Philadelphia PP. 80-109.

Kiessling, C.R.; Mare Jakson, Watts, K.A.; Loftis, M.H.; Kiessling W.M.; Buen, M.B.; Laster, E.W. and Sofos, J.N. (2007): Antimicrobial susceptability of Salmonella isolated from various products, from 1999 to 2003. J. Food Prot. 70: 13341338 . 
Krushna, N.S.; Kowsalya, A.; Radha, S. and Narayanan, R.B. (2007): Honey as a natural preservative of milk. Indian. J. Exp. Biol. 45: 459-64.

Larocco, K.A. and Martin, S.E. (1987): Development of stress and survival of salmonella typhimurium ATCC 7136 in a tapioca soystarch product containing potassium sorbate. J. Food Safety, 8: 279-284.

Liewen, M.B. and Marth, E.H. (1985): Growth and inhibition of microorganisms in the presence of sorbic acid: A Review. J. Food Prot. 48: 364-375.

Luck, E. (1980): Antimicrobial food additives, springer veriag. New York. 183- 199.

Lusby, P.E.; Coombes, A.L. and Wilkinson, J.M. (2005): Bactericidal activity of different honeys against pathogenic bacteria. Arch. Med. Res. 36: 464-7.

Molan, P. (1992): The antibacterial activity of honey 1- The nature of The Antibacterial activity. Bee World, 73:5-28.

Mundo, M.A.; Padilla-zakour, O.I. and Worobo, R.W. (2004): Growth inhibition \& food borne pathogens and food spoilage organisms by select raw honeys. Int. J. Food Microbiol. 97:1-8.

Nasseib, T.A.; ElDin, M.Z. and El-Sharoud, W.M. (2003): Assessment of the presence of salmonella spp. in Egyptian dairy products using various detection media. Lett. App. Microbiol 37: 405409.

Olsen, S.J.; Mackinon, L.C.; Goulding, J.S.; Bean, N.H. and Slutsker, L. (2000): Surveillance for Foodborne disease outbreaks - United States, 1993 - 1997. Surveillance Summaries 49 (SSOL):1- 51.

Park, H.S. and Marth, E.H. (1972): Inactivation of S. typhimurium by sorbic acid. J. Milk Food Technol. 35: 532-539.

Rice, K.M. and pierson, M.D. (1982): Inhibition of Salmonella by sodium nitrite and potassium sorbate in frankfurter. J. Food Sci. 47: 1615- 1617.

Rohrbach, B.W.; Draughon, F.A.; Davidson, P.M. and Oliver, S.P. (1992): Prevalence of L. monocytogenes, C. jejuni and Salmonella in bulk tank milk, risk factors and risk of human exposure. J. Food Prot. 55: 93-97.

Russel, K.M.; Molan, P.C.; Wilkins, A.L. and Hiland, P.T. (1990): Identification of some antibacterial constituents of New Zealand manuka honey. J. Agric. Food Chem. 38: 10-13. 
Sayed, M. (2002): Polyamine patterns of some microorganisms isolated from environment, milk and soft cheese. Ph. D. thesis Fac. Vet. Med. Assiut Univ.

Sharma, V.D.; Dixit, V.P. and Joshi, R.K. (1995): Occurrence of salmonella in foods of animal origin with special reference to antibiogram and enterotoxigeicity. J. Food Sci., Technol. 32(3): 221-223.

Sofos, J.N. and Busta, F.F. (1981): Antimicrobial activity of sorbate. J. Food Prot. 44: 614-622

Somal, N.A.; Coley, K.E.; Molan, P.C. and Han Cock, B. M. (1994): Susceptibility of Helicobacter pylori to the antibacterial activity of manuka honey. J. R. Soc. Ned 87: 497-498.

Stephen, A.N. and Caren, E.M. (1997): Microbiology Laboratory Manual, principles and application. Prentice Hall, inc. Upper Seddle River, New Jersy.

Troutt, H.F.; Galland, J.C.; Osburn, B.I.; Brewer, R.L.; Braun, R. K.; Schmitz, J.A.; Seras, P.; Childers, A.B.; Richey, E.; Mather, E.; Gibson, M.; Marthy, K. and Hogue, A. (2001): Prevalence of Salmonella spp. in cull (market) dairy cows at slaughter, J. Am. Vet. Med. Assoc. 219: 1212-1215.

Tuncan, E.U. and Martin S.E. (1985): Effect of $\mathrm{pH}$, temperature and potassium sorbate on amino acid up take in S. typhimurium 7136. App. Environ. Microbiol, 49:505-508

Zansky, S.; Wallace.; Schoon maker-Bopp, D.; Smith, P.; Ramsey, F.; Painter, J.; Gupta, A.; Kalluri, P.; and Noviello, S. (2002): From the Centers for Disease Control and Prevention. Outbreak of multidrug resistant Salmonlla newport ... USA: JAMA 288: 951-953.

Varnam, A.H. and Sutherland, J.P. (1994): Milk and Milk Products Technology, Chemistry and Microbiology $1^{\text {st }}$ Ed. Chapman and Hall pub London

Wang, M.; Ran, L.; Wang, B. and Li, Z. (2004): Study on national active monitoring for food borne pathogens and antimicrobial resistancc in China 2001. Weisheng Yan Jiu, 33: 49-54.

WHO (1998): Regional office for Europe, 7th report of the WHO surveillance program for the control of food borne infections and intoxications in Europe (1993-1998).

WHO (2002): First pan- European conference on food quality and safety: Foodborne diseases are on the rises in Europe - FAO WHO call for better consumer protection. 
Table 2: Stability of $S$. enteritidis against pot. sorbate and honey in cream held at refrigeration temperature.

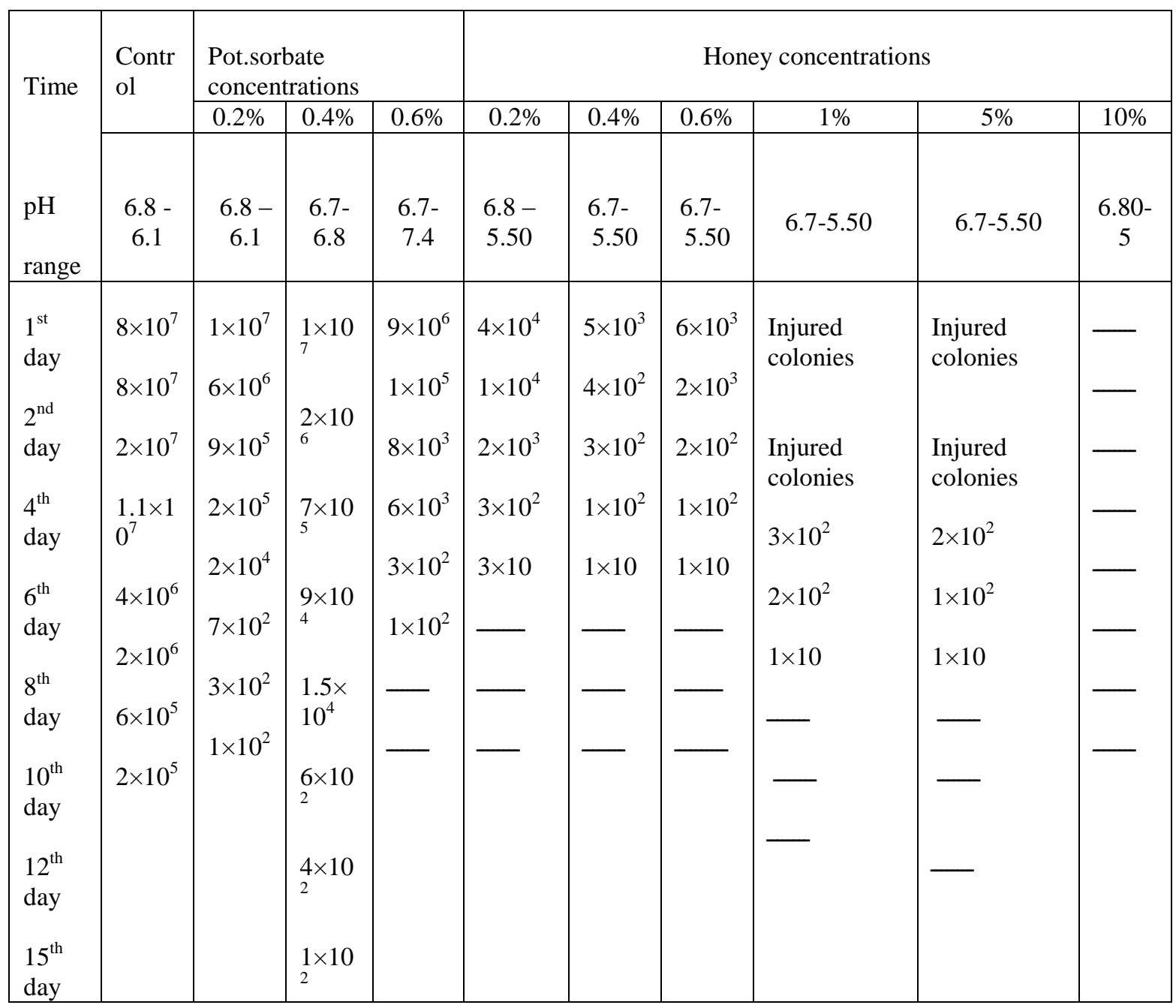

Initial count $=1 \times 10^{7} \mathrm{cfu} / \mathrm{g}$ 